\title{
МЕТОДЫ ГОСУДАРСТВЕННОГО РЕГУЛИРОВАНИЯ РЕЛИГИОЗНОЙ ПРАКТИКИ ПЕЩЕРНИЧЕСТВА
}

\section{METHODS FOR STATE REGULATION OF RELIGIOUS CAVING PRACTICE}

Yu. Poleva

Summary: The article highlights the main stages of state regulation of religious life and ascetic practice of cave asceticism in the South of Russia during the 17th - early 20th centuries; forms of asceticism in various confessional groups are considered: Orthodox, Old Believers and sectarian. The author analyzes the reasons for the growing popularity of cave digging and cave asceticism in modern times, during the period of persecution by the secular and church authorities of individual forms of asceticism and the consequences of such a policy on the development of cavemen.

Keywords: cave hermitage, cave digging, cave seclusion, Old Belief, dissident communities, deviation, Ortodox Church Belief, confessional persecution.
Полева Юлия Владимировна

К.и.н., старший преподаватель, ФГБОУ ВО «Волгоградская государственная академия физической культуры» poleva_yuliya@mail.ru

Аннотация: В статье выделяются основные этапы государственного регулирования религиозной жизни и аскетической практики пещерного подвижничества на Юге России на протяжении XVII-н.XX вв.; рассматриваются формы аскезы в различных конфессиональных группах: православных, старообрядческих и сектантских. Автор анализирует причины роста популярности пещерокопательства и пещерного подвижничества в новое время, в период преследования со стороны светской и церковной власти индивидуальных форм подвижничества и последствия такой политики на развитие пещерничества.

Ключевые слова: пещерное подвижничество, пещерокопание, пещерный затвор, старообрядчество, секты, девиация, православие, религиозные гонения.
$\mathrm{H}$ а протяжении длительного периода с XVII по первую треть XX в. на территории Нижнего Поволжья и Подонья, развивалась крайняя форма аскетического подвижничества в форме пещерокопательства и пещерного затвора. Объединяя нередко значительные общины, пещерничество создавало определенные образцы поведения более значимые для адептов, чем общепринятые нормы, а часто и более значимые, чем действующие законы государства, регулирующие религиозное поведение. Это ставит перед нами проблему, как юридически государство пыталось регулировать эту форму подвижничества; какие методы применялись и насколько успешно осуществлялся такой контроль.

Немаловажным мотивом подземного затвора было стремление «скрыться» «бежать от мира». Говоря о выработке подземных полостей для культовых практик, необходимо оговорить вопрос о том, что есть норма и что есть девиация для «пещерного делания», конечная цель которого понималась как «подвиг» для «спасения души».

Обширный пласт православной житийной литературы, дает канонический образец пещерного подвижничества в обоих формах: «пещерокопательство» и «пещерный затвор». Благодаря Киево-Печерскому патерику эти формы подвижничества вдохновляют все новых адептов вплоть до XX в. То есть мы видим, что пещерничество задано как особая норма поведения, поощряемая именно как подвиг. Светская власть в средневековье не претен- дует на вмешательство в регулирование поведения монахов как церковных людей. Такая позиция власти опиралась на действующее законодательство, известное как «Устав Владимира Святого» [1. 544-545]. Запрет на вмешательство светской власти в церковные дела восходит к византийскому сборнику церковного права VI-VII в. «Номоканону». В глазах светского человека русского средневековья пещерник - человек однозначно святой. А вот внутри самой церкви не было единого отношения к пещерничеству как к безусловной норме монашеского подвига. Это хорошо проявляется в патериках, например, в «Киево-Печерском патерике» [2. 7-81] в эпизодах о первоначальном запрете игуменом пещерного затвора для будущих святых Никиты и Лаврентия затворников. Жития этих святых раскрывают историю дьявольского прельщения этих монахов в пещере, что чуть не завершилось их гибелью. Такие же эпизоды мы видим в Синайском патерике, повествующем о подвижничестве раннехристианского монашества. То есть сфера применения «пещерного делания» в монашестве, на самом деле был ограничен самой церковью. Оно признавалось возможным только для опытных в духовной брани подвижников, умеющих отличать «хитрые обольщения сатаны от действий благодати»[3. 190]. Нельзя сказать, что устав полностью определял развитие традиции этой формы подвижничества на юге России. Напротив, стремление к индивидуальной аскезе, к пустынничеству, безмолвию, пещерному деланию приводило к уходу некоторых монахов и создание пустыней в отдаленных ме- 
стах. Например, Донские казаки почитали основателей Кременской Вознесенской обители - семерых братьев, являвшихся современниками Ермака'. Пещеры в Каменном байраке близ монастыря, согласно преданию, были местом их подвижничества [4. 168-172].

Церковный собор 1666-1667 определивший раскол русской православной церкви, породил новое явление убеждение, что поскольку нечестием людей «на тридцать сажен осквернена земля» [5. 249-258], то единственное спасение для христианина возможно в результате разрыва всех социальных связей, бегства от мира в пещеры: «Уходите вы, мои светы, Вы во горы, во вертепы, Вы во пропасти земныя. Засыпайтесь вы, мои светы, Вы пеплами и песками, еще мелкими хрящами. Вы постойте, мои светы, за крест и за молитву, и за веру християнскую» [6. 15]. Эта мысль проходит красной нитью через старообрядческие стихи, псалмы и пр. Власть в лице царя Алексея Михайловича и смещенного патриарха Никона воспринимаются староверами как «два рога антихриста». То есть мы видим, что религиозный кризис получил политический контекст. Этот кризис достиг своего апогея во время старообрядческой войны. 1686-1688 гг. на Дону. Восставшие требовали прежде всего отмены реформ патриарха Никона, исправлений книг и обрядов. Центром восстания стали меловые горы на Медведице близ устья р. Арчеда. Спецификой восстания было присутствие в руководстве двух старцев-пещерников с Волги. Сам предводитель восставших казаков-старообрядцев Кузьма Косой именовал себя «Святогорским», что опять претендует на придание сакральной легитимности социальному конфликту. Кузьма Косой был казнен после многочисленных пыток, а вот судьба старцев нам до конца не известна. «А в Медведице реке, которые были в горах Кузьки Косого советники и те все такоже собрався, вышли в далние места в вершину реки и живут в крепя ${ }^{2}$ близко Танбова и Козлова и расколу не отстанут» [7. 2196]. Необходимо помнить, что эти события приурочены к периоду дуумвирата Петра и Иоанна Алексеевичей под регентством царевны Софьи. Софья проявила себя как жесткий преследователь старообрядцев еще в 1685 г. были приняты «Двенадцать статей царевны Софьи», где старообрядцев, отказывающихся принять исправления, приказывалось пытать и в случае упорства «жечь в срубе и пепел развеять» [8. 419-422]. Тем не менее, сама практика личной аскезы не подвергалась юридическому регулированию.

Становление абсолютизма, оформление Российской империи в правление Петра I кардинально изменило положение института церкви в государстве. Ее превращение фактически в имперский бюрократический аппарат привело к усилению государственного контроля над всеми формами религиозной жизни в России.

Создание Святейшего правительствующего синода в 1721 г. способствовало развитию таких социальных функций религии, как использование религиозных санкций в качестве форм социального контроля общества, а также для поддержания стабильности существующего государственного порядка. В новом политическом контексте индивидуальный мистический религиозный опыт, как императив, получаемый напрямую «сверхъестественным» образом, был антагонистичен церкви как бюрократическому институту.

B 20-х гг. XVIII В. предпринимается ряд шагов, по ограничению народных форм религиозности, понимаемых властью как суеверия: Принят ряд указов, упразднявших часовни: деревянные подлежали сносу, каменные употреблению на иные нужды; снимались надвратные иконы; изымались чудотворные иконы в ризницы кафедральных соборов [9. 187-193]. В том числе было запрещены странничество, затворничество, столпничество и прочие особо суровые индивидуальные формы аскезы, которые могли усилить авторитет личности подвижника в ущерб авторитету института церкви [10. л.245].

Однако народная религиозность по-прежнему преимущественно поддерживала подвижников. Христианское мученичество за веру стало такой же нормой для церковного сознания, как и аскетизм еще во II-III в., когда мученичество было «самым сильным доказательством истины христианства» [11. 56]. В целом на протяжении всего XVIII в. намечалось некоторое смягчение государственной политики по отношению к старообрядцам, хоть они и подвергались религиозной дискриминации: не могли занимать государственных и иных должностей, обкладывались двойным подушным налогом и т.д. Но жестокие условия «двенадцати статей царевны Софьи» прекратили свое действие еще при Петре І. Положение старообрядцев значительно было облегчено в правление Петра III и Екатерины II. Однако, личная аскеза, в том числе пещерничество подвергалось жестким преследованиям, как явная девиация, при том преступного характера. Пещерников подозревали как минимум в мошенничестве, а также в изуверстве, фальшивомонетничестве ${ }^{3}$ и т.д. Редкое исключение о признании новых

1 «...Нам передавали, что когда копали ямы для крестов, то находили человеческие кости, основываясь на древних преданиях, кости эти считаются костями семи братьев. По одному акту, хранящемуся в Донской консистории, убийство это относится ко времени Ермака». См.: Кременский Вознесенский монастырь// Войсковые областные ведомости: часть неофициальная. 1876. № 4.

2 Крепь горная, искусственное сооружение, возводимое в подземных выработках для предотвращения обрушения.

3 А. Артемьев отмечал, что в с. Синенькие, где существовала секта подпольников, развиты фальшивомонетничество и подделка документов. Подобные же обвинения в адрес старообрядческого монаха Антония, при этом с указанием на изготовление фальшивых денег именно в пещере мы встречаем у Леопольдова в «Историческом очерке Саратовского края». Подобный вид деятельности, очевидно, связан с общей концепцией легитимности власти у этого направления сектантства 
рукотворных пещер православными Синодом было сделано для Белогоских пещер Воронежской епархии. Однако путь признания пещер, выкопанных М. Шерстюковой и ее поклонниками был не прост. Борьба между местными иерархами РПЦ и пещерокопателями завершилась неожиданным вмешательством императора Александра I, признавшего эти пещеры[14. 34].

В 1764 г. по указу Екатерины II были секуляризованы монастырские земли. Монахи стали получать жалование согласно штатному расписанию. Штатные монастыри были разделены на три класса, но многие выведены за штат и упразднены. Такая судьба постигла Мигулинский, Усть-Медведицкий и Кременско-Вознесенский монастырь. Позже Войско Донское добилось восстановления двух последних, за штатом, на содержании от Области Войска Донского. С этого времени в запустение приходят многие пещерные монастыри в Воронежском Подонье. Шатрищегорский пещерный монастырь также был упразднен, но по-прежнему посещаем паломниками. Гражданским властям было поручено уничтожить пещеры. Полиция у пещер столкнулась с местным населением, которое встало на защиту почитаемой святыни. В итоге «пещеры остались открыты и еще более чтимы» [13. 811]. Этот конфликт наглядно иллюстрирует, что народные представления о святости не всегда совпадали с церковными.

Представление о святости пещер среди простого народа распространяется как на признанные православной церковью пещеры, так и на пещеры, принадлежащие иным толкам. Как оказалось, органы власти не располагали реальными возможностями (ни догматическими, ни идеологическими, ни карательными), чтобы справиться с таким массовым проявлением народных убеждений. Многие пещеры оказались завалены, а пещерокопатели разогнаны, но развитию пещерокопательства это не препятствовало. В Белогорском и Шатрищегорском монастырях, как и в других случаях, губернские и епархиальные органы власти оказались вынуждены идти на компромисс с верующими. Конфликт между властью и простым народом нарастает и государство не находит эффективных инструментов для его регуляции. Конфликт во многом опирается на своеобразный «цивилизационный раскол» российского общества, образовавшийся в итоге реформ Петра I, на секулярную прозападническую культуру (город и высшие сословия) и почвенничество (крестьянство, составлявшее абсолютное большинство населения России). Этот «цивилизационный раскол», на самом деле объективно был неизбежен для русской цивилизации, вступившей в Новое время. По мере развития городской секулярной культуры, политических реформ на базе философии Просвещения и развития промышленности неизбежно нарастали противоречия между архаизированым миром крестьянской общины и рациональным миропониманием элит, в том числе и церковных. Излишнее молитвенное усердие мирянина казалось церкви подозрительным, вызывало нередко расследование по подозрению в уклонении в раскол или сектантство. Политика Синода была не в состоянии успешно решать нарастающие противоречия с народной религиозностью, и мы видим, что радикальные формы личной аскезы процветают, пещерничество развивается, особенно активно в различных сектах и разных старообрядческих толках. Особенно наглядно это прослеживается на материале Нижнего Поволжья и Нижнего Подонья.

С 1827 г. переход в старообрядчество стал уголовным преступлением. Подземные сооружения, создаваемые различными толками старообрядчества, выполняли важную функцию сохранения этих конфессиональных групп. Скрытность становится одним из распространенных атрибутов подземных культовых сооружений. Это отражается на материале уединенных старообрядческих скитов, возобновляющих весьма архаичные представления о пещере как сакральном помещении и убежище от преследования светских гонителей [14. Л.218].

После разгрома Иргизских монастырей 28 мая 1841 г. центр Поволжского старообрядчества сместился в Хвалынск, где на горах Черемшана с XVII в. существовали старообрядческие скиты. Политическое преследование старообрядчества не способствовало преодолению раскола, а провоцировало развитие антагонистических отношений между преследователями и гонимыми, находивших выражение, в том числе, в пространственных категориях. Интегративной основой для гонимых старообрядцев остается обращение к «древлему благочестию» принципам понятным и привлекательным для простого населения. Личная аскеза и пещерный затвор были наиболее наглядным их воплощением. Отношения полиции к пещерным практикам старообрядцев хорошо раскрыта Л.Т. Мизякиным на материале Черемшанских скитов: «...Здесь, в глуши лесов, в трущобах и пещерах затеплились первые лампады и по ночам раздавались молитвенные гимны. Время от времени наезжали светские и духовные власти с понятыми. Разметывали "гнездилище разврата раскольнического", одних вязали и заковывали, других разгоняли... Все это вело лишь к тому, что люди подвигались все глубже и глубже в леса, отыскивали более скрытные пустыни, зарывались в подземелья, и в результате возникали новые обители и общежития» [15. 6].

Фактически сами преследования способствовали формированию таких представлений о подземном пространстве как об убежище и как основе новой, антагонистической легитимной, структуры. Психологически закреплялось представление о «спасительности» даже временного подвига пещерничества. Эти представления часто попадали даже в обыденную жизнь старообрядцев: «В России тогда для старообрядцев было суровое бесправное время. Грамота раскольникам в то время была строжайше запрещена, вследствие чего 
о. Серапион, будучи еще мальчиком, должен был уходить в погреб, чтоб почитать какую-нибудь книгу. Все это известным образом сказалось на его характере» [15. 11]. Несмотря на общую институализацию и бюрократизацию религиозной жизни в православной церкви в этот период, авторитет личности, ведущей подвижнический образ жизни, оставался по-прежнему высок и даже мог вызвать сочувствие властей: «Местное начальство очень уважало о. Серапиона... Власти г. Хвалынска часто посещали Черемшан, особенно летом. Нередко можно было видеть исправника, беседующего с о. Серапионом, а пристав С... прямо покровительствовал Черемшану. Этим можно объяснить то обстоятельство, что Черемшан за все время существования ни разу почти не подвергался репрессиям со стороны полиции» [15. 14]. Личная харизма о. Серапиона и подвижнический образ жизни являются лишь одной из предпосылок своеобразной ситуации, сложившейся на Черемшане. Ведь лояльное отношение местных властей к старообрядческим скитам здесь было довольно распространено, на что жаловались миссионеры и иерархи. И система взяток, обеспечивавшая лояльность властей, лишь подтверждала, что сложившаяся старообрядческая коммуникационная система паломничества к Черемшанским святыням вполне эффективно обеспечивает устойчивое существование здесь скитов.

Эти старообрядческие скиты являлись некоторое время резиденцией старообрядческих иерархов Белокриницкого согласия, которые находились под особым наблюдением полиции, поэтому были предусмотрены подземные тайники на территории скитов. Л.Т. Мизякин во время своего пребывания на Черемшане описал один из таких тайников: «На Черемшане для Афанасия (старообрядческий епископ Белокриницкого согласия. - Ю.П.) было устроено под беседкой подземелье, куда его и прятали в минуту опасности. Пол в беседке пригнан так искусно, что никому и в голову не придет, что он легко поднимается и опускается» [15. 38].

Уход под землю также являлся отражением социального протеста против светской власти и православной церкви - «истинные христиане всегда были гонимы», как любил повторять о. Илиодор.

Традиция пещерничества в старообрядчестве характерна для всего Поволжья. Так, А.И. Артемьев в отчетах статистической экспедиции по Саратовской губернии отмечал: «От города вниз по Волге поповская секта перешла уже в другую секту... Спасова согласия. Между этими селами примечательно с. Воскресенское (государственные и удельные крестьяне). В горах, окружающих село, скрываются беглые, землянки, в которых они живут, были неоднократно уничтожаемы, но на их месте всегда устраиваются новые» [14. 218 об].

Эта же традиция со всеми характерными особенностями развивалась в Области Войска Донского. Так, ста- рожилы станицы Нижне-Каргальской сообщали о разгроме старообрядческого скита, находящегося в балке близ станицы, но при этом добавляли, что два старика сумели избежать гонений [16. 9]. Можно сказать, что воспроизводимость и развитие этих толков, несмотря на преследования, были вполне успешны.

В период Великих реформ сложилась в целом более либеральная обстановка, но нельзя сказать, что контроль над сектантами и старообрядцами ослаб. По прежнему Синод требовал тщательного учета всех уклонившихся от православия, по прежнему полиция расследовала все выявленные случаи подземножительства, однако, чиновник статистического комитета МВД А.И. Артемьев в результате экспедиции по саратовской губернии пришел к выводу, что благочинные, полиция утаивают истинное положение дел, что бы не портить статистику. В своем статистическом отчете по состоянию раскола в Саратовской губ. А.И. Артемьев описывает распространенный факт, что «между беглопоповскими селениями образуется отдельная республика, пользующаяся громкой по всей стране славой... Зимой беглецы скрываются в подпольях у своих странноприимцев, а летом в окружающих село горах» [17. л.33. об.]. Мы видим, что своеобразная старообрядческая субкультура продолжает развиваться и в пореформенный период, усложняясь новыми толками.

В сектантских комплексах, где пещерное пространство воспринималось как антагонистическое наземному-греховному, пещерокопательство сопровождалось такими дезинтегративными процессами, как разрыв с семьей и своей социальной средой. Иван Черкасов осуждал безродненских духобратцев в том числе и за то, что мужчины и женщины шли в пещерное братство и оставляли окончательно домашнюю работу - честный труд и жили здесь «на людях» [18. 204]. В ситуациях, когда активизируются эсхатологические ожидания, пещера становится убежищем, местом, где «истинные христиане» способны спастись во время грядущего конца света и получить доступ в Царствие небесное.

Рост радикальных сект можно связать с ростом общественных движений в период великих реформ и промышленной революции. Реформы болезненно отозвались на уровне жизни крестьянства. Отсутствие рабочего законодательства ухудшало и без того тяжелое положение пролетариата, формирующегося из разоренного крестьянства. Неприятие разрушения традиционных патриархальных схем отношений между властью и народом принимало ожидаемую форму эсхатологических ожиданий. Встречаются групповые самоубийства сектантов в пещерах. Их масштаб не сопоставим с гарями последней трети XVII в., однако, каждый инцидент крайне болезненно воспринимался общественностью. Так в Поволжье в селе Синенькие, зафиксирован и описан обряд «Красной смерти», где больного сектанта за- 
колачивали в гроб, утыканный гвоздями и катали с горы, пока больной не умрет. В Поволжье этот обряд в д. Копены Саратовской епархии [17. л.33. об.]. В местной пещере произошло самоссожение сектантов. Подобный же эпизод описан в д. Костенки Воронежской Епархии [20. 42]/. Этот изуверский обряд воспринимался сектантами как своеобразный акт мученической смерти.

Законодательно ситуация кардинально изменилась под влияние первой русской революции 1905-1907 гг., когда были приняты «Основные законы российской империи». В этот период был принят закон о свободе вероисповедания. Поражение России в Русско-японской войне обнажило всю глубину кризиса политической системы, достигшего общенационального масштаба и выразившегося в революции 1905 - 1907 гг. Любой кризис сопровождается дезинтегративными процессами не только в экономической, политической и идеологической сферах, распаду подвергаются традиционный уклад, духовные ценности. Епархиальные отчеты периода первой русской революции фиксируют два основных процесса в духовной жизни своей паствы. Во-первых, мощный процесс секуляризации сознания, как православного населения, так и старообрядческой молодежи. Второй процесс отражал нарастание эсхатологических ожиданий среди сектантов. В условиях дестабилизации системы возрастает значение «религиозных виртуозов», которые предлагали верующим религиозные способы регулирования такого кризиса. Как правило, такие лидеры обладали сильной личной харизмой.

Массовое религиозное движение, возникшее под руководством о. Илиодора в Царицыне, можно рассматривать как своеобразную реакцию на нарастающую дезинтеграцию общества в кризисных условиях, разложение моральных и идеологических критериев всего общества, что вызывало дезориентацию личности, кризис ценностных норм. В 1911-1912 гг. иеромонах Илиодор (Сергей Труфанов) создает в Царицыне грандиозный пещерный комплекс, насчитывавший три яруса [21. л.254.]. Мотивация его создания сочетала в себе как политические, так и эсхатологические моменты. Однако теперь губернское жандармское правление в большей степени интересует политическая лояльность религиозных общин, чем степень их соответствия православию.

Тем не менее, необходимо признать, что именно закон о свободе вероисповедания 1905 г. сделал более, нежели все миссионеры Святейшего Синода за XVIII-XIX вв. Он уничтожил основной посыл, который поддерживал радикальные религиозные движения: «Истинная церковь всегда гонима». Страдания за веру, скрытничество потеряли свой смысл, что повлияло на секуляризацию народных масс в целом. К сожалению, кризис ценностных норм в революционный период придал новый смысл сектантскому движению, привел к новым жертвам. Например, Традиционные эсхатологические ожидания шашковцев обострились в связи с образованием колхозов: «Наступает свету конец, - сказал он, - антихрист возликовал на грешной земле. Конец наступает христианству! Всех православных гонят в колхоз! Конец света! Кто хочет со мной замуроваться в Сионе пусть остается на месте. Кто не хочет - пусть облачается в мирские одежды и уходит в мир - не перечу! Даже благословляю!» [22. л.425.]. Возобновление практики добровольной смерти в радикальных сектах (душиловцы, скрытники, подпольники) мотивируется близостью конца света и Страшного суда. Преследования светской власти воспринимается как своеобразный знаменатель эсхатологических ожиданий в радикальных сектах и предвещает гибель мира, и определяет посмертную участь смирившихся с «антихристовым царством».

Добровольная смерть является способом преодоления насилия государства и истинным спасением в глазах сектанта. В некоторых случаях удавалось зафиксировать, что сектанты, принявшие решение о ритуальном самоубийстве, находились в экстатическом состоянии. Пещера, как сакрально выделенное пространство, воспринимается в качестве своеобразного перехода для «избранных» к царству Божьему. Таким образом наземное «профанное» пространство в религиозных представлениях противопоставлялось сакральному подземному пространству, свободному от контроля светской и церковной власти.

\section{ЛИТЕРАТУРА}

1. Списки церковного устава святого Владимира. Список обширной редакции// митр. Макарий (Булгаков). История Русской Церкви. 12 томов. Т 2. Изд.: Спасо-Преображенского Валаамского монастыря. - М. 1994.

2. Киево-Печерский патерик // Древнерусские патерики. - М.: Наука, 1999. - С. 7-81.

3. Устав общежит. монастыря, писанный для Коневской обители: Прибавл. 4, гл.1 и 3 // Петр (Екатериновский, еп.). Правила и практика православной аскезы / Еп. Петр (Екатериновский). - СПб.: Статисъ, 2002. - 190 с.

4. Попов Н. Семибратская могила / Н. Попов // Воронежские епархиальные ведомости. - 1868, приложение к № 6. - С. 168-172.

5. Мельников-Печерский П.И. Собрание сочинений в 6 т. - М., Правда, 1963. Т.1, с. 249-288.

6. Духовные учителя сокровенной Руси. СПб.: Изд-во «Питер», Серия «Лабиринты истории», - 2007. - 320 с.

7. Дополнения к Актам историческим собранным и изданным археографической комиссией. - СПб., 1872. - Т. XII. 
8. Акты, собранные в библиотеках и архивах Российской империи Археографическою экспедицией Академии наук. Т. 4. - СПб., 1836. С. 419-422. № 284.

9. Чистяков П.Г. Почитание местных святынь в российском православии синодального периода // Православный собеседник: Альманах Казанской Духовной Семинарии. Вып. 1(14)-2007. Материалы VI ежегодной научно-практической конференции «Богословие и светские науки: традиционные и новые взаимосвязи». Казань, 2007. С. 187-193.

10. РГИА. Ф. 796. Оп. 2.. № 422/394. Л. 245.

11. Сидоров А.И. Древнехристианский аскетизм и зарождение монашества. / А.И. Сидоров. - М.: Православный паломник, 1998.- 472 с.

12. Белогорские пещеры: Издание вновь открытой при Белогорских пещерах Воскресенской обители. - Павловск, 1889. - 71 с. (без сост.)

13. Шатрищегорский монастырь // Воронежские епархиальные ведомости. - 1875. - № 13. - С. 811- 822.

14. Артемьев А.И. «Сборник о раскольниках». Записки, отчеты, и прочее разных лиц, 1875 г. // РНБ. Отдел рукописей. - Ф. 37. №39. 1875. 256 л.

15. Мизякин Л.Т. Черемшан / Л.Т. Мизякин. - Саратов, 1909. - 76 с.

16. Из Донской старины. Ст-ца Нижне-Каргальская // Казачий вестник. - 1884. - № 19.

17. Артемьев А.И. Краткая записка о современном положении раскольников в Саратовской губернии. // РНБ. Отдел рукописей. - Ф.37. № 273. 26.09.1855. 68 л.

18. Черкасов И. Повесть о безродненских пещерокопателях в Астраханской губернии / И. Черкасов // Астраханские епархиальные ведомости. - 1889. С. 28992; 305-310; 352-60; 401-410; 447-454; 486-96; 529-37; 590-598; 615-629.

19. РГИА. Ф. 797. Оп. 67. 2 отд-ние. 3. Стол. № 169. По записке министра юстиции о заживо погребенных сектантах в Терновских плавнях близ г. Тирасполя. Л. 506 .

20. Степкин В.В. История изучения культовых пещерных сооружений бассейна Дона и Оскола/ В.В. Степкин // Культовые пещеры Среднего Дона: сб.ст./ Сост. М.Ю. Сохин. - Вып. 4. М. - 2004. -С. 18-29.

21. ГАВ0. Ф. 6. Оп. 1. Д. 273.

22. Агарков В.А. Трудное детство. Мемуары. Рукопись // Фонд музея с. Заплавное, Волгоградской области 1988 г. - 525 с.

(с) Полева Юлия Владимировна (poleva_yuliya@mail.ru).

Журнал «Современная наука: актуальные проблемы теории и практики»

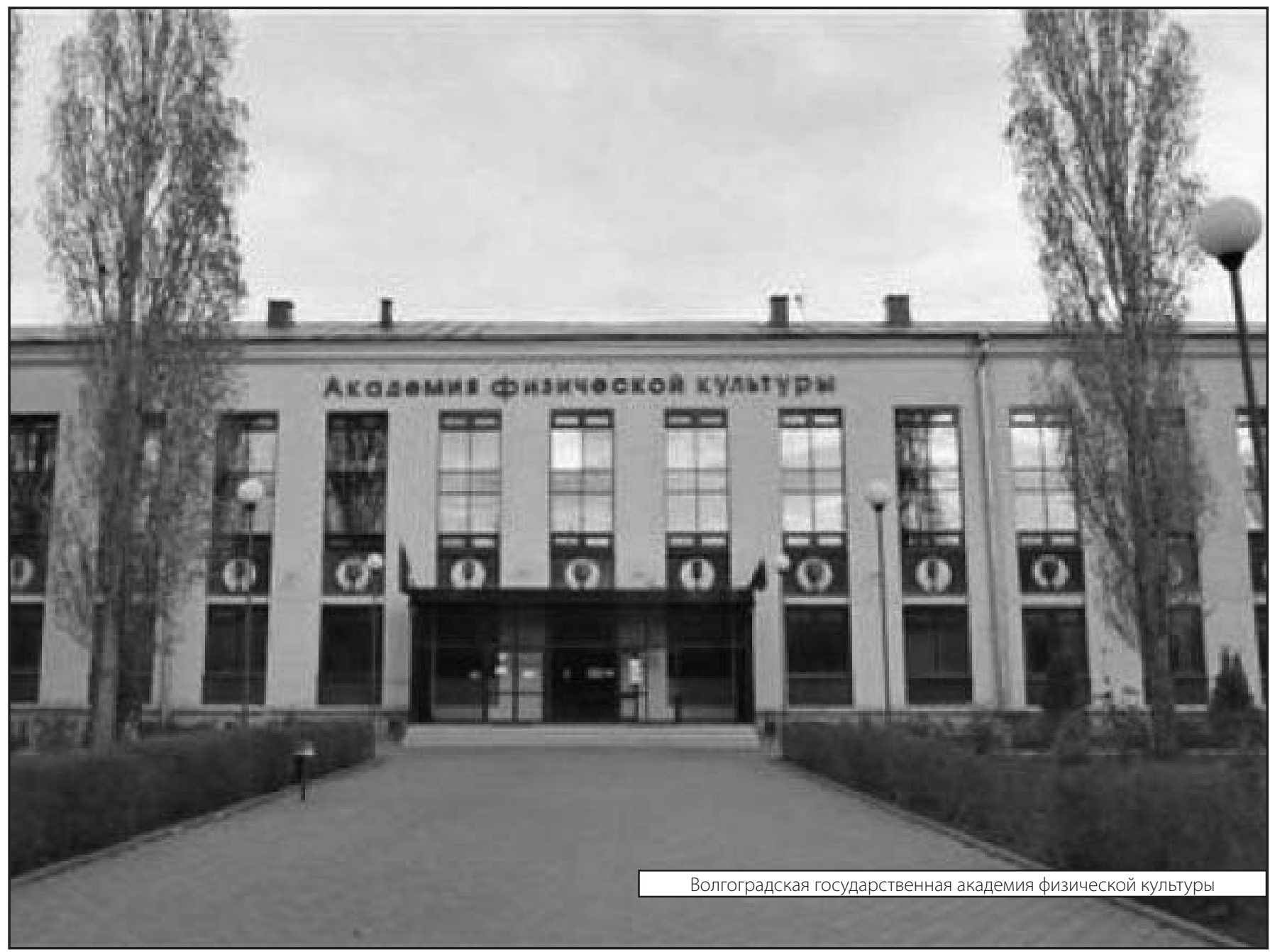

